\title{
SURVEY ON NUTRITIONAL STATUS OF SCHOOL CHILDREN AFTER THE FLOOD IN CENTRAL KYUSHU, May 261953
}

\author{
IICHIRO CHIN, SHUICHI UCHIBAYASHI, YOSHIO HATASE, \\ JUN-ICHI TOYODA, SHIRO NAKAMURA, SHOICHI KARA- \\ SHIMA, OSAMU OKADA, HIROSHI OKI, ISAO KUNITAKE, \\ TAKAHIDE NAKAMURA, TSUTOMU MATSUSHITA, SEIYA \\ YAMAKAWA, NOZOMU YOKOO, KOTOKU OYAMA, \\ SHIGEMI OKI, MASAYUKI YAMAGUGHI
}

Department of Pediatrics,* Kurume University School of Medicine, Kurume-shi, Japan

The greatest flood among those in recent sixty years attacked most severely the areas along the River Chikugo, the biggest one in Kyushu, May 26. 1953, and went down slowly from damaged districts four days later from its outbreak. One hundred and forty seven deaths among 5,000 casualties and a loss of about $\$ 36,180,000$ exhibit really the catastrophic aspects of this flood. The disturbances of communication and transportation long enough to interrupt the re-establishment of all of social and economical features in the damaged districts contributed to the aggravation of livelihood of peoples in the flooded towns and villages.

The purpose of this paper is to observe how have been the children cared for under these situations of emergency by means of survey on nutritional status and have been they improved thereafter by public and other aids from the viewpoint of Genève Declaration.

\section{SUBJECTS AND METHODS}

All the school boys of 3rd and 6th grade of Zendoji Primary School, respectively 60 and 47, out of total seven hundred school children were studied, whose school situates besides the River Chikugo in the middle area of the Chikugo plane and was one of the most severely damaged. The severity of their hard life after the flood would be supposed from the degree of submergence of their houses under water during four days (Tab. 1).

The first survey was made on these boys on the 11th of Sept. 1953 and the second, on the 7th of Feb. 1954 after delivery of UNICEF food supply, in oder to elucidate the serious effects of disastrous circumstances upon the nutritional status of children,

* Director: Prof. I. Chin, M.D. 
and to evaluate their recovery from them.

Each method of investigations is presented in each section.

\section{RESULTS}

\section{(1) Clinical observation}

The nutritional status of boys is divided into three groups: eutrophic $\mathrm{A}$, moderate $\mathrm{B}$ and undernourished $\mathrm{C}$ through synthetic observation of body weight, development of subcutaneous adipose tissue and characteristics of skin. Pallor of skin, anemia of visible mucous membranes, stomatitis, presumably caused by $\mathrm{B}_{2}$ deficiency and the accentuation of pulmonal 2nd sound as a symptom of $B_{1}$ deficiency were also observed.

As shown in Tab. 2, the percentage of A-grouped boys increased to $25 \%$ from $13 \%$, that of C-grouped decreased to $4 \%$ from $9 \%$ in the 2 nd survey, and the great majority of anemic and pale boys had recovered at the time of the 2nd survey in comparison with those in the 1st survey. As to the deficiencies of vitamines, the lowering of accentuation of pulmonal 'znd sound was perceived later, except the persistence of stomatitis, insomuch as is recognized usually in children in rural districts.

TABLE 2

Clinical observation of school boys

\begin{tabular}{|c|c|c|c|c|c|c|c|c|c|c|c|}
\hline \multirow{2}{*}{$\begin{array}{l}\text { Date of } \\
\text { inves- } \\
\text { tigation }\end{array}$} & \multirow{2}{*}{$\begin{array}{l}\text { Clinical } \\
\text { No. data } \\
\text { of boys } \\
\text { of grade }\end{array}$} & \multicolumn{3}{|c|}{$\begin{array}{l}\text { Nutritional } \\
\text { status }\end{array}$} & \multirow[t]{2}{*}{$\begin{array}{l}\text { Pallor } \\
\text { of skin }\end{array}$} & \multirow{2}{*}{$\begin{array}{l}\text { Anemia of } \\
\text { mucous } \\
\text { membra- } \\
\text { nes }\end{array}$} & \multicolumn{3}{|c|}{$\begin{array}{l}\text { Degree of } \\
\text { stomatitis }\end{array}$} & \multicolumn{2}{|c|}{$\begin{array}{l}\text { Accentuation } \\
\text { of pulmonal } \\
\text { 2nd sound }\end{array}$} \\
\hline & & A & $\mathrm{B}$ & $\mathrm{C}$ & & & 1 & 2 & 3 & 1 & 2 \\
\hline \multirow{5}{*}{$\begin{array}{l}\text { Sept } \\
1953\end{array}$} & 3rd grade & 6 & 49 & 5 & 22 & 12 & 7 & 4 & 3 & 9 & 8 \\
\hline & 6 th grade & 8 & 34 & 5 & 11 & 3 & 7 & 3 & 0 & 7 & 1 \\
\hline & \multirow{2}{*}{ Total } & 14 & 83 & 10 & 33 & 15 & 14 & 7 & 3 & 16 & 9 \\
\hline & & \multicolumn{3}{|c|}{107} & 33 & 15 & \multicolumn{3}{|c|}{24} & \multicolumn{2}{|c|}{25} \\
\hline & $\%$ & 13.1 & 77.5 & 9.5 & 30.8 & 14.0 & \multicolumn{3}{|c|}{22.2} & \multicolumn{2}{|c|}{23.3} \\
\hline \multirow{5}{*}{$\begin{array}{l}\text { Feb. } 7 \\
1954\end{array}$} & 3rd grade & 15 & 37 & 3 & 0 & 0 & 11 & 7 & 2 & 7 & 2 \\
\hline & $\begin{array}{l}6 \text { th R } \\
\text { grade }\end{array}$ & 10 & 34 & 1 & 1 & 1 & 3 & 1 & 1 & 6 & 2 \\
\hline & $\mathrm{T}$ & 25 & 71 & 4 & 1 & 1 & 14 & 8 & 3 & 13 & 4 \\
\hline & Plat & & 100 & & 1 & 1 & & 25 & & \multicolumn{2}{|c|}{17} \\
\hline & $\%$ & 25.0 & 71.0 & 4.0 & & & \multicolumn{3}{|c|}{25.0} & \multicolumn{2}{|c|}{17.0} \\
\hline
\end{tabular}

From these clinical observation, the malnutrition of boys seemed to be improved 
markedly except the persistence of $\mathrm{B}_{2}$-deficiency. According to health supervision of teachers in charge, pupils were quite well, ran vigorously and played satisfactorily in the play ground in the autumn and winter, while they looked pale and exhaustive in the late summer soon after the flood.

\section{(2) Measurement of body}

The growth of body weight, body length and circumference of chest are illustrated in Tab. 3, in which the 3rd grade boys showed the normal development, but those of the 6 th grade were not significantly normal during these five months.

TABLE 3

Measurement of body

\begin{tabular}{|c|c|c|c|c|c|c|c|c|c|c|c|c|c|c|}
\hline \multirow{2}{*}{$\begin{array}{l}\text { Date of } \\
\text { invest i- } \\
\text { gation }\end{array}$} & \multicolumn{7}{|c|}{ Sept. 111953} & \multicolumn{6}{|c|}{ Feb. 71954} & \multirow{2}{*}{$\begin{array}{l}\text { Signific- } \\
\text { ance of } \\
\text { dif- } \\
\text { ference }\end{array}$} \\
\hline & $\begin{array}{l}\text { Gr- } \\
\text { ade }\end{array}$ & $n \mid$ & $\mathrm{M} \pm \mathrm{m}$ & $\alpha$ & $\mathrm{V}$ & $\operatorname{Max}$ & Min. & $\mathrm{n}$ & $\mathrm{M} \pm \mathrm{m}$ & $\alpha$ & V & Max. & Min. & \\
\hline \multirow{2}{*}{$\begin{array}{l}\text { Body } \\
\text { weight } \\
\text { (Kg.) }\end{array}$} & 3 & 60 & $23.5 \pm 0.3$ & $|2.34|$ & 14.20 & 29.5 & 19.0 & 55 & $25.6 \pm 0.4$ & 2.88 & 11.41 & 31.0 & $19.5^{\prime}$ & $\begin{array}{l}\text { Signif. } \\
\text { Increase }\end{array}$ \\
\hline & 6 & 47 & $30.1 \pm 0.5$ & 3.69 & 12.26 & 40.0 & 23.2 & 46 & $32.3 \pm 0.7$ & 4.39 & 13.59 & 43.3 & 23.7 & none \\
\hline \multirow{2}{*}{$\begin{array}{l}\text { Body } \\
\text { length } \\
\text { (Cm.) }\end{array}$} & 3 & 601 & 120 & 4.02 & 3.33 & 131.3 & 111.3 & 551 & 123 & 4.67 & 3.78 & .0 & 111.8 & f. \\
\hline & 6 & 47 & $135.0 \pm 0.7$ & 4.56 & 3.38 & 146.5 & 114.0 & 461 & $138.1 \pm 0.9$ & 6.35 & 4.59 & 152.2 & 123.6 & none \\
\hline \multirow{2}{*}{$\begin{array}{c}\text { Circum- } \\
\text { ference } \\
\text { of chest } \\
(\mathrm{Cm})\end{array}$} & 3 & 59 & $59.8 \pm 0.3$ & 2.47 & 4.13 & 65.5 & 55.0 & 55 & $62.4 \pm 0.4$ & 2.80 & 4.49 & 68.0 & 55.0 & $\begin{array}{l}\text { Signif. } \\
\text { Increase }\end{array}$ \\
\hline & 6 & 47 & $65.3 \pm 0.4$ & 3.05 & 4.67 & 74.7 & 61.0 & 46 & $67.1 \pm 0.5$ & 2.75 & 4.10 & 75.2 & 61.2 & none \\
\hline
\end{tabular}

\section{(3) Findings of blood}

Hemoglobin content of blood, number and sedimentation rate of erythrocytes and hematocrit value with routine methods, protein content of serum with copper sulfate methode and $\mathrm{A} / \mathrm{G}$ ratio with viscosimeter were determined. Results are shown in Tab. 4 .

Boys of the 3rd grade showed the significant increase of hemoglobin content and hematocrit value, whereas the persistence of hypochromic anemia was observed among the boys of 6 th grade. In average, protein content and $A / G$ ratio of serum and sedimentation rate of eryrhtocytes recovered to the normal value, although their extreme values must have been taken in consideration in details. Five boys, whose proteinemia was lower than $6.9 \mathrm{~g} \%$ and $\mathrm{A} / \mathrm{G}$ ratio was outside the range of normal ratio $1.3-1.7$, decreased in number to 2 in regard to the same criteria at later survery. And four boys with abnormal A/G ratio among 6 hyperproteinemics (over $8 \mathrm{~g} \%$ ) increased to 7 boys among 27 hyperproteinemics, being predominated mainly in the 6th grade. Nine boys of the 6 th grade, whose hemoglobin content was lesser than $10 \%$, increased to 21 at the 2nd survey, in contrast with the decrease in number of boys from 30 to 14 in the 3 rd 
grade. Eleven boys in each grade with pathological sedimentation rate of erythrocytes (higher than $20 \mathrm{~mm}$ per hour) reduced to half of them later. Since the hyperglobulinemia accompanied with hyperproteinemia is assumed as a sign of dystrophia, some serum lability tests were performed. Positive Kunkel and cephalin choresterol reactions were found more frequently in boys of the 6 th grade than in those of 3rd grade at each of surveys, while positive Gros reaction was revealed in the same rate in boys of both the 3rd and 6th grade. In all, the percentage of malnutritive boys decreased to $10 \%$ from initial $20 \%$.

TABLE 4

Fintings of blood

\begin{tabular}{|c|c|c|c|c|c|c|c|c|c|}
\hline \multirow{2}{*}{\multicolumn{2}{|c|}{$\begin{array}{l}\text { Date of } \\
\text { investigation } \\
\text { Findings of } \\
\text { blood } \\
\end{array}$}} & \multicolumn{8}{|c|}{ Sept. $11 \quad 1953$} \\
\hline & & Grade & $\mathrm{n}$ & M & $\mathrm{m}$ & $\alpha$ & $\mathrm{V}$ & Max. & Min. \\
\hline \multicolumn{2}{|c|}{ Hemoglobin (g/dl) } & $\begin{array}{l}3 \\
6\end{array}$ & $\begin{array}{l}61 \\
47\end{array}$ & $\begin{array}{l}10.00 \\
11.00\end{array}$ & $\begin{array}{l}0.13 \\
0.22\end{array}$ & $\begin{array}{l}1.00 \\
1.54\end{array}$ & $\begin{array}{r}9.96 \\
13.96\end{array}$ & $\begin{array}{l}12.75 \\
14.85\end{array}$ & $\begin{array}{l}4.95 \\
8.10\end{array}$ \\
\hline \multicolumn{2}{|c|}{$\begin{array}{l}\text { No. of erythrocy- } \\
\text { tes } \\
\text { (Thousand/cmm) }\end{array}$} & $\begin{array}{l}3 \\
6\end{array}$ & $\begin{array}{l}60 \\
41\end{array}$ & $\begin{array}{l}3,485.8 \\
3,611.6\end{array}$ & $\begin{array}{l}91.4 \\
68.6\end{array}$ & $\begin{array}{l}197.9 \\
439.3\end{array}$ & $\begin{array}{r}56.8 \\
121.6\end{array}$ & $\begin{array}{l}4,250 \\
4,950\end{array}$ & $\begin{array}{l}2,650 \\
2,700\end{array}$ \\
\hline \multicolumn{2}{|c|}{$\underset{(\%)}{\text { Hematocrit value }}$} & $\begin{array}{l}3 \\
6\end{array}$ & $\begin{array}{l}58 \\
48\end{array}$ & $\begin{array}{l}34.62 \\
34.31\end{array}$ & $\begin{array}{l}2.90 \\
2.94\end{array}$ & $\begin{array}{l}22.09 \\
20.49\end{array}$ & $\begin{array}{l}9.27 \\
5.97\end{array}$ & $\begin{array}{l}39.0 \\
38.7\end{array}$ & $\begin{array}{l}30.0 \\
30.2\end{array}$ \\
\hline \multicolumn{2}{|c|}{ A/G Ratio } & $\begin{array}{l}3 \\
6\end{array}$ & $\begin{array}{l}64 \\
46\end{array}$ & $\begin{array}{l}1.38 \\
1.36\end{array}$ & $\begin{array}{l}0.04 \\
0.02\end{array}$ & $\begin{array}{l}0.38 \\
0.15\end{array}$ & $\begin{array}{l}27.22 \\
11.36\end{array}$ & $\begin{array}{l}2.33 \\
2.57\end{array}$ & $\begin{array}{l}0.59 \\
0.23\end{array}$ \\
\hline \multicolumn{2}{|c|}{$\begin{array}{c}\text { Proteinemia } \\
\qquad(\mathrm{g} / \mathrm{d} 1)\end{array}$} & $\begin{array}{l}3 \\
6\end{array}$ & $\begin{array}{l}58 \\
46\end{array}$ & $\begin{array}{l}7.40 \\
7.63\end{array}$ & $\begin{array}{l}0.05 \\
0.05\end{array}$ & $\begin{array}{l}0.45 \\
0.33\end{array}$ & $\begin{array}{l}6.14 \\
4.36\end{array}$ & $\begin{array}{l}8.25 \\
8.14\end{array}$ & $\begin{array}{l}6.55 \\
6.96\end{array}$ \\
\hline \multicolumn{2}{|c|}{$\begin{array}{l}\text { Sedimentation rate } \\
\text { of erythrocyte } \\
\text { ( } \mathrm{mm} \text { in one hour) }\end{array}$} & $\begin{array}{l}3 \\
6\end{array}$ & $\begin{array}{l}60 \\
46\end{array}$ & $\begin{array}{l}14.75 \\
15.85\end{array}$ & $\begin{array}{l}1.60 \\
1.78\end{array}$ & $\begin{array}{l}12.37 \\
12.04\end{array}$ & $\begin{array}{l}83.86 \\
75.97\end{array}$ & $\begin{array}{l}51.0 \\
55.0\end{array}$ & $\begin{array}{l}2.0 \\
2.0\end{array}$ \\
\hline \multicolumn{10}{|c|}{ Feb $7 \quad 1954$} \\
\hline $\mathrm{n}$ & M & \multicolumn{2}{|c|}{$\mathrm{m}$} & \multicolumn{2}{|l|}{ a } & $\mathrm{V}$ & \multicolumn{2}{|c|}{ Max. } & Min. \\
\hline $\begin{array}{l}53 \\
46\end{array}$ & $\begin{array}{l}10.77 \\
10.12\end{array}$ & \multicolumn{2}{|c|}{$\begin{array}{l}0.13 \\
0.19\end{array}$} & \multicolumn{2}{|l|}{$\begin{array}{l}0.91 \\
1.31\end{array}$} & $\begin{array}{r}8.45 \\
13.01 \\
\end{array}$ & \multicolumn{2}{|c|}{$\begin{array}{l}13.08 \\
13.65\end{array}$} & $\begin{array}{l}4.50 \\
4.50\end{array}$ \\
\hline $\begin{array}{l}53 \\
46\end{array}$ & $\begin{array}{l}3,598.6 \\
3,362.8\end{array}$ & \multicolumn{2}{|c|}{$\begin{array}{l}65.2 \\
04.7\end{array}$} & \multicolumn{2}{|l|}{$\begin{array}{l}472.6 \\
438.5\end{array}$} & $\begin{array}{l}131.3 \\
130.3\end{array}$ & \multicolumn{2}{|c|}{$\begin{array}{l}4,600 \\
4,550 \\
\end{array}$} & $\begin{array}{l}2,500 \\
2,650\end{array}$ \\
\hline $\begin{array}{l}50 \\
45\end{array}$ & $\begin{array}{l}38.90 \\
38.49\end{array}$ & \multicolumn{2}{|c|}{$\begin{array}{l}0.33 \\
0.28\end{array}$} & \multicolumn{2}{|l|}{$\begin{array}{l}0.23 \\
0.24\end{array}$} & $\begin{array}{l}8.38 \\
6.21 \\
\end{array}$ & \multicolumn{2}{|c|}{$\begin{array}{l}46.55 \\
43.50\end{array}$} & $\begin{array}{l}34.65 \\
35.00\end{array}$ \\
\hline $\begin{array}{l}50 \\
45\end{array}$ & $\begin{array}{l}1.69 \\
1.66\end{array}$ & \multicolumn{2}{|c|}{$\begin{array}{l}0.05 \\
0.04\end{array}$} & \multicolumn{2}{|l|}{$\begin{array}{l}0.36 \\
0.28\end{array}$} & $\begin{array}{l}21.45 \\
16.77\end{array}$ & \multicolumn{2}{|c|}{$\begin{array}{l}2.45 \\
2.35\end{array}$} & $\begin{array}{l}0.90 \\
1.05\end{array}$ \\
\hline $\begin{array}{l}50 \\
45\end{array}$ & $\begin{array}{l}7.64 \\
7.77\end{array}$ & \multicolumn{2}{|c|}{$\begin{array}{l}0.07 \\
0.06\end{array}$} & \multicolumn{2}{|l|}{$\begin{array}{l}0.52 \\
0.39\end{array}$} & $\begin{array}{l}6.79 \\
4.97\end{array}$ & \multicolumn{2}{|c|}{$\begin{array}{l}9.18 \\
8.51\end{array}$} & $\begin{array}{l}6.81 \\
6.69 \\
\end{array}$ \\
\hline $\begin{array}{l}53 \\
46\end{array}$ & $\begin{array}{l}8.01 \\
5.65\end{array}$ & \multicolumn{2}{|c|}{$\begin{array}{l}1.44 \\
1.39\end{array}$} & \multicolumn{2}{|l|}{$\begin{array}{r}10.42 \\
9.45\end{array}$} & $\begin{array}{l}130.08 \\
167.30\end{array}$ & \multicolumn{2}{|c|}{$\begin{array}{l}50 \\
52\end{array}$} & \\
\hline
\end{tabular}


From these findings of blood, the following conclusion was obtained that latent malnutrition of boys persisted on longer after the damage, even if they looked to be improved fairly.

(4) Investigation of home-prepared lunch

As the malnutrition seemed to prevail among school children at the beginning of survery, we attempted to know the diet taken by boys in several days before the survey by question at first. They took chiefly rice only, or occasionally rice mixed with wheat in small amount as the staple foodstuff, and dried fish, distributed canned fish and raw fish as sources of animal protein, in addition to soup, made of fermented soya-beans (Misoshiru), cooked onion, pumpkin and other vegetables. The question on diet in next year revealed slightly varied and enriched foods. And then, to be sure of daily diet of pupils, we examined without previous announcement the homeprepared lunch, which pupils themselves bring to school every day as the usual manner of school children in rural districts. Lunches of 55 boys contained fish, eggs, whale meat and others as sources of animal protein besides considerable amount of rice as main source of caloric requirement, and animal protein intake by lunch was $35 \mathrm{~g}$ per boy in average in this group. Those of remaining 48 boys contained vegetables only and five boys were lack of lunch. In the 2nd survey, 27 boys brought mainly fish, whose animal protein intake was $36 \mathrm{~g}$ per boy in average, 40 boys were only of vegetable diet, 32 boys only of $120-150 \mathrm{~g}$ weightened bread without butter, and 4 boys were lack of lunch.

In Tab. 5, total calories and protein intake by lunch are calculated all over the school boys of each grade. The amount of total calories ranged from 502 to 520 cal, and it decreased to $403 \mathrm{cal}$ in younger boys at the 2 nd survey. Protein intake was invariably $12.5 \mathrm{~g}$ per boy for all boys at both the 1 st and 2 nd survey, because main source of protein derived from rice. In the 2 nd survey, it is $11.2 \mathrm{~g}$, or 11.9 for boys of $3 \mathrm{rd}$ grade, and $13.0 \mathrm{~g}$, or $14.7 \mathrm{~g}$ for boys of 6 th grade, whether boys fed only by bread were included, or excluded in statistic.

This investigation of lunch has revealed that protein intake $12.5 \mathrm{~g}$ per boy is half the certified amount of standard lunch regimen for Japanese school children, and animal protein occupied only one fourth of it, viz. $3.2 \mathrm{~g}$ per boy.

As was previously observed, the fact that the malnutrition of younger boys has improved considerably up to the later survey in spite of their incomplete diet, may be explained partially with food supply by UNICEF. Supply schedule is shown in Tab. 6. Boys recieved $44 \mathrm{cal}$. and $4.4 \mathrm{~g}$ of animal protein, in addition to 3.2 protein from lunch. With this supplementary milk, younger boys took $0.69 \mathrm{~g}$ of animal protein 
TABLE 5

Survey on lunches of boys

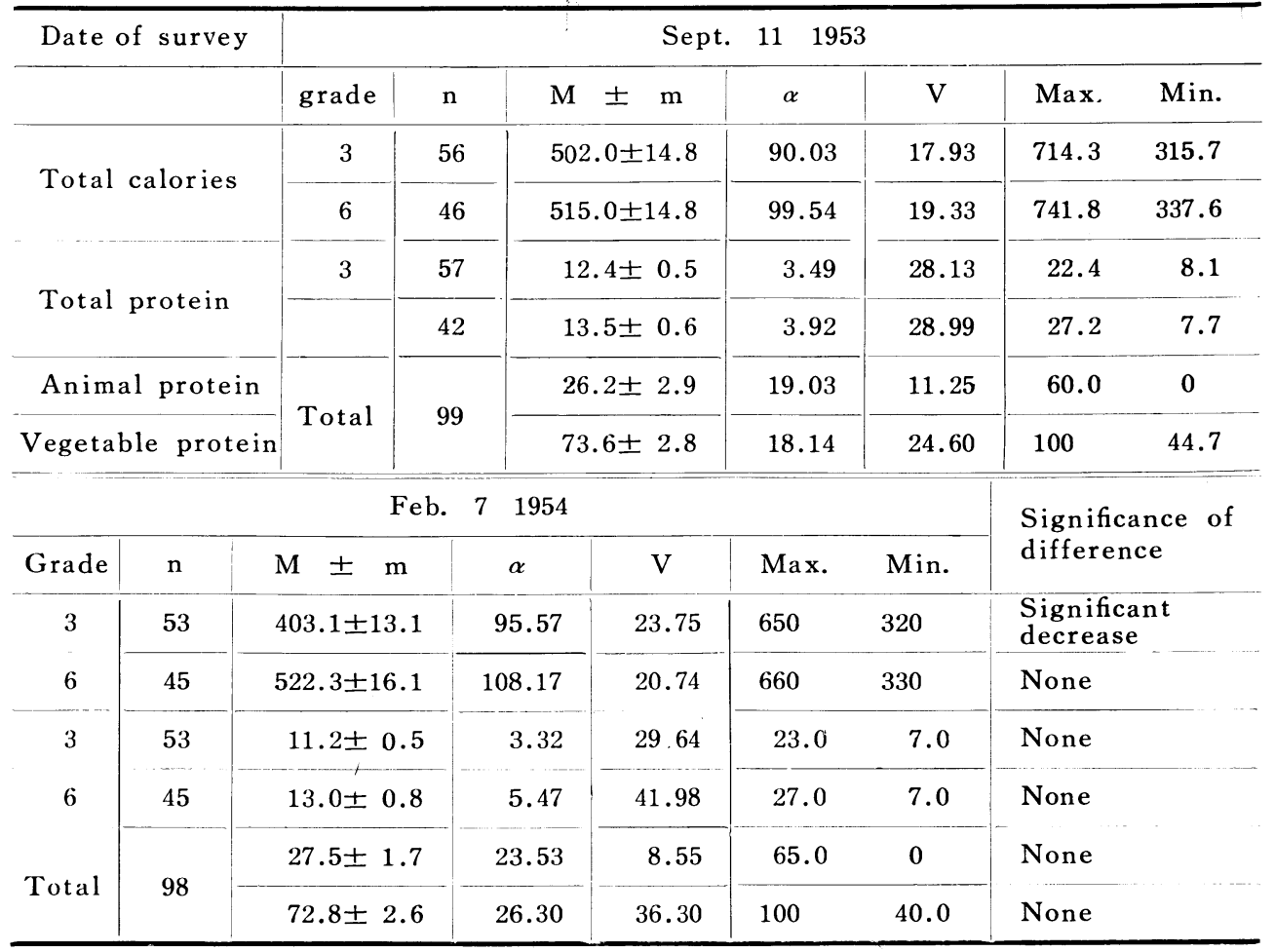

per kilogram of body weight instead of $0.49 \mathrm{~g}$, taken formerly and older boys, $0.53 \mathrm{~g}$ instead of $0.41 \mathrm{~g}$.

TABLE 6

Date of delivery and amount of UNICEF food supply

\begin{tabular}{l|c}
\hline $\begin{array}{l}\text { Period of } \\
\text { food supply }\end{array}$ & $\begin{array}{c}\text { Food } \\
\text { supply }\end{array}$ \\
\hline Oct. 1953 & 16 \\
\hline Nov. 1953 & 16 \\
\hline Dec 1953 & 18
\end{tabular}

$22 \mathrm{gm}$. skimmed milk per day to each boy (containing protein $8 \mathrm{gm}$. and 80 cal.)

$$
\begin{aligned}
& \text { Calories per day }=\frac{80 \times 50}{90}=44 \mathrm{cal} . \\
& \text { Protein per day }=\frac{8 \times 50}{90}=4.4 \mathrm{gm} .
\end{aligned}
$$

Total 90 days 50 days

Consituent of skimmed milk by UNICEF (per 100gm)

$\begin{array}{lclr}\text { Calories } & 363.6 & \text { Protein } & 36.36 \\ \text { Carbohydrate } & 52.49 & \text { Fat } & 0.91\end{array}$

In general, half of school children in rural districts lacked of the animal protein 
in their lunches, and they were delightful of taking skimmed milk together with their lunches. In order to achieve the effective nutrition with food of relief under such as disastrous circumstances, it is postulated that adequate protein intake of children must be attained to as soon as possible.

\section{COMMENT}

Economically, the harvest of rice in 1953 reduced to $63 \%$ of ordinary one as a result of deterioration of farms in this area and almost all the peoples were obliged to live their hard days in their damaged home. Such unfavorable environments after the great flood continued longer enough to affect the child health, although the extraordinary relief act for disaster was officially administrated exceptionally long for one month. Therefore, even two months after the flood, twenty percent of children were still suffered from malnutrition, to which attributed chiefly the deficiencies of protein and vitamines, as was revealed through the unbalanced lunch in quality of school boys. The apparent recovery of undernourished boys, however, took place at last, whereas the findings of blood revealed the hypochrome anemia and dysproteinemia as the evidence of latent malnutrition, especially in older boys.

The food gratefully granted from UNICEF was not able to improve sufficiently the undernourishment of older boys, while it brought about moderate effects to nutrition of younger boys. It would contribute to regain the health of children more effectively, provided the supply should be delivered as soon as possible after the flood and its amount had attained to more than $22 \mathrm{~g}$ per day, presumably $45 \mathrm{~g}$.

\section{SUMMARY}

1. The survey on nutritional status was performed about all the 60 boys of 3rd grade and 47 boys of 6 th grade of Zendoji primary school in the most severely damaged area, twice on Sept. 111953 and Feb. 71954 after the great flood in May 261953.

2. From clinical observation, the percentage of anemic and malnourished boys decreased to $4 \%$ in 2 nd survey from $10 \%$ in 1 st survey, except invariably remained sign of vitamin $\mathrm{B}$ deficiencies, although the measurement of body detected no marked retard of development.

3. From biochemical findings of blood, however, the percentage of dysproteinemic and anemic boys decreased to only $10 \%$ in 2 nd survey from $20 \%$ in 1 st survey, insatisfactory improvment being found mainly in older boys. Serum lability tests revealed much less evidence of latent malnutrition. 
4. In both 1st and 2nd survey, the investigation of home-prepared lunches of school boys showed that each lunch, in average, contained 500 cal. mainly from rice and $12.5 \mathrm{~g}$ of protein, of which one fourth. viz. $3.2 \mathrm{~g}$ was of animal protein, because the main source of protein derived from rice as staple foodstuff. Observed in details, the percentage of pupils, whose lunches consisted of vegetable food only increased to $72 \%$ in 2 nd survey from $46 \%$ in 1 st survey and about five boys lack of lunch were encountered on each occasion.

5. UNICEF has supplied to children $22 \mathrm{~g}$ of skimmed milk per boy per day during three months, which added $44 \mathrm{cal}$. and $4.4 \mathrm{~g}$ of animal protein to each lunch with the results of remarkable improvement of malnutrition of younger boys.

6. We recognised by means of survey on nutrition that school children have not been cared for satisfactorily after the catastrophic flood. Among relief works of emergency, especially the nutritive requirement of children must be fulfilled as soon as possible and prolonged enough to secure their health under the situations of serious disaster. 